\title{
Solomos Solomou
}

\section{Trade Protection in the 1930s}

Post-war policy makers created the foundations of a new international economic order around a number of beliefs about inter-war trade policy: protection and depression were seen to be inextricably related in a causal manner, as was protection and the disintegration of world trade and the collapse of multilateralism. This view continues to find support today (Capie, 1992; Capie, 1994). However, the picture of inter-war protection that is emerging in recent research is far more complex: some countries gained, others lost. Some trading blocs were able to expand trade in the adverse circumstances of the 1930s, others were not successful at doing so (Eichengreen and Irwin, 1993; Kitson and Solomou, 1990; J. ForemanPeck et al., 1992).

In order to understand why countries chose protectionism in the early 1930s it is not sufficient simply to argue that protection policies were an outcome of interest group policies that did not serve countries well. We need to understand the historical context of this policy response. Two key features need to be emphasised: first, the 1930 s was a period when existing institutions were failing to generate high employment and output levels; secondly, the policy framework was still very much based on national decision making, with very limited international policy co-ordination. In such circumstances it is possible that trade protection offered an appropriate national response to external shocks. It is misleading simply to point to the lost opportunities that accompanied the abandonment of free trade. Countries had the choice of raising interest rates and deflating further to control their worsening balance of payments problems or to protect. Protection offered a viable national-specific policy option.

This picture differs from that drawn by policy makers in the early post-war period. To reconcile these differing views it is important to realise that post-war policy makers were attempting to build the foundations for a New Economic Order by creating institutions that were going to re-stabilise the world economy in the long run (such as GATT). A qualified evaluation of the protectionist measures adopted during the inter-war era would not have been a politically viable way of generating institutional change. However, one important function of historical analysis is to identify the complexities of actual policy choices.

Business cycle shocks during the inter-war period had persistent effects on aggregate macroeconomic performance partly because the inter-war epoch did not 
have an equivalent set of international adjustment mechanisms to the pre-1913 era. The pre-1913 gold standard survived for so long partly because there existed viable international adjustment mechanisms to national-specific shocks, including international migration flows, trade protection and overseas investment (which stimulated the tradable sector). These adjustments manifested themselves in long swing fluctuations in a number of international economic variables, such as exports, overseas investment and international migration (Solomou, 1998). The inter-war era saw an abrupt end of many of these adjustment outlets. Legislation in the New World prevented mass emigration as a solution to mass unemployment. The disintegration of world trade, partly due to protection policies and a collapse of overseas investment during 1928-38, prevented export growth from stabilising the effect of domestic demand shocks. Instead, severe business cycle shocks left economies with high unemployment and low output levels. The 'passing of the Kuznets cycle' (Abramovitz, 1968) in the inter-war era is of central importance to business cycle experiences, just as the presence of Kuznets swings before 1914 represented the workings of various stabilising cyclical adjustment mechanisms in the international economy. The occurrence of large shocks and the failure to co-ordinate policy at the international level meant that national policy responses had to be pursued and trade policy offered a direct response to serious balance of payments problems.

The type of insights we gain from analysing the inter-war period can help us think about the type of pressures we might expect in future periods. It would be ahistorical to argue that particular regions should learn from the experience of the 1930 s and avoid protection at all costs. The optimal policy response of the regions of the world economy must be a function of the nature of shocks and the nature of the adjustments that are possible (including the degree of international policy coordination). Judged in this context the protectionism of the 1930s was a rational response to specific historical circumstances that determined policy options. Pointing out that a different mix of institutions can result in improved economic performance may be sobering but anachronistic.

During the 1930s Government policies disrupted the flow of international trade with higher levels of tariffs. Quotas were also used on an extensive basis for the first time, particularly in France and Switzerland. International trade also became increasingly discriminatory, leading to the development of trading blocs between Britain and its Empire, Germany and Eastern Europe, Japan and the 'Yen Bloc', France and its Empire.

The discriminatory protection policies in the inter-war years are also assumed to have led to a collapse of multilateral trade (Pomfret, 1988; League of Nations, 1939). Both Britain and Germany practiced discriminatory trade policies in the 1930 s and saw a proportion of their trade being managed with bilateral trading agreements. To evaluate the effects of these developments I consider two aspects of tariff policy in the 1930s. First, section I sets up a framework for analysing the national effects of tariffs. This is then used to evaluate the impact of tariffs on Britain. Section II considers the question of whether the world economy witnessed a 
collapse of multilateralism using long run quantitative evidence from the trade patterns of the major industrial economies.

\section{National Effects of Tariffs}

In considering the national effects of tariff policies during the 1930 s the following aspects need to be considered:

\section{'Initial conditions'}

The initial state of an economy may affect its response to protection in the circumstances of the 1930s. Thus, economies that failed to reconstruct successfully in the 1920 s, burdened with slow economic growth and overvalued exchange rates may behave differently to the more competitive economies. Thus, if the sectors protected in the 1930s were facing adverse competitive conditions in the 1920s (as in the case of Britain), protecting these sectors may have given them the necessary time to adjust, stimulating cyclical growth.

\section{'Beggar-thy-Neigbbour' effects}

The initial benefits of a change in trade policy may be negated by the impact of retaliation and the decline in world trade. What proportion of the decline in world trade can be attributed to protectionism? The existence of 'trading blocs' complicates the analysis significantly. The alternatives are not simply rapid growth of world trade or slow growth of world trade; the growth of 'trading blocs' provided a means for some economies to expand trade.

\section{Qualitative Policy Shifts}

One needs to distinguish between quantitative increases in existing tariff rates and a policy regime shift towards protection. For example, most of British industry operated under free trade rules until the inter-war period. Thus, the policy initiated by the General Tariff of 1932 can be viewed as a qualitative shift and its effects would be expected to be different from the policy adjustment of many other economies, which simply involved raising tariffs from already existing high levels.

\section{Balance of Trade Effects}

Lewis (1949, pp. 59-61) suggests that the spread of protectionism may have had beneficial effects in reducing the amplitude of the downswing but negative effects during the upswing. Lewis argues that if one country cuts its imports then trading partners whose exports have fallen must cut their imports to maintain trade balance. To achieve external balance without recourse to policy their overall level of imports will have to fall by some multiple of their deficit, resulting in deflation. The introduction of a tariff allows trade flows to be adjusted in a targeted way, arresting the need for internal deflation. 


\section{The Overall Policy Regime}

The effects of tariffs will be influenced by the nature of the exchange rate regime. In a simple macroeconomic model, to the extent that a tariff improves the trade balance it may act to appreciate the nominal exchange rate; to the extent that a tariff is a price raising measure it will act to appreciate the real exchange rate. However, such simple models rarely provide an accurate description of the way economies respond in historical time. In the circumstance of managed exchange rates in the 1930 s the effects on the nominal exchange rate may be filtered via policy feedback. Empirical evidence also teaches us that "history matters". Even if a tariff has effects on the real exchange rate there may be enough time for significant adjustments to have been made. Thus we need to be aware of the possibility of hysteresis effects that may arise from trade policy, whereby a transitory event may result in longer-term effects. During the 1930s the links between protection and exchange rates are even more perverse. Countries that used protection as a means of sustaining the gold parity were more likely to face adverse effects than countries combining protection with devaluation. Thus, although all countries were raising tariff rates in the 1930s, in analysing the effects of these policies we need to allow for interactions between protection and exchange rate regime.

\section{The structure of Protection}

To better understand the expected impact of a tariff structure we need information on both the nominal and effective rates (Capie, 1983). Effective rates are important to determining the relative magnitudes of protection afforded to different industries. The nature of tariff changes varied significantly across countries. For example, in the case of the UK, protection was offered to the industrial sector but not to food and raw materials; in contrast, in France the rise of tariff rates was mainly on food and agricultural products. Inter-sectoral effective rates need to be considered in conjunction with intra-sectoral rates: thus, a non-tradable sector, such as building, that uses tradable inputs will be adversely affected by the price effects of a tariff structure. Within a particular sector different industries will receive different levels of effective protection.

Such effects are likely to lead to a diversity of impacts at the national level. Setting out the aggregate effect on the world economy then becomes extremely difficult. This framework will be used to evaluate the effects of the General Tariff of 1932 on Britain during the 1930s. In a more speculative way the section also uses this framework to consider the effects of French protection during the 1930s.

In February 1932 the UK imposed a General Tariff of 10 per cent ad valorem on imports from foreign countries: this was a protectionist device designed to shield the domestic industrial sector from foreign competition. To appreciate the nature of the change in Britain's trade policy we need to place it in the wider context of protectionism in the world economy. The UK was the only major industrial country to pursue a unilateral free trade policy in the period 1870-1913. Even by 1925 the limited extent of protection in the UK meant that the average tariff level on manufactured goods was only 5 per cent ad valorem: the McKenna Duties 
(1915) and the Safeguarding of Industries Act (1921) had already protected some of the new industries such as motor cars, chemicals and scientific instruments. In contrast, the average tariff for Continental Europe was 25 per cent (Liepmann, 1938) and the United States 37 per cent (Bairoch, 1986; Eichengreen, 1989).

The early 1930s saw a sharp rise in tariff levels and quotas throughout the world economy, initially induced by falling food and raw material prices in 1928-29 which forced many European countries to raise the level of agricultural protection in order to alleviate distress in the sector. Such trends suggest that to analyse the effects of the General Tariff the relevant question that needs to be addressed is whether the UK pursued an appropriate second best trade policy in the 1930s in the context that the world trading system was already highly distorted. A policy of continuing with unilateral free trade, which assumes no existing distortions, was simply not viable.

Given that a tariff creates a wedge between domestic and foreign prices a starting point for analysing the effects of the General tariff is to consider effects on prices. The pricing response of domestic and foreign producers to changes in tariff rates is critical to determining the magnitude of change in competitiveness. If domestic producers simply use the protection afforded by tariffs to raise prices and foreign producers respond to the loss of competitiveness by cutting prices, competitiveness may, in fact, be little changed. Such information on the 'pass-through' properties of the tariff requires a disaggregated analysis of the pricing behaviour of domestic and foreign firms. This issue was partially addressed in a contemporary Board of Trade analysis of the General Tariff by Leak (1937). Leak considered the impact of the tariff on import prices relative to domestic prices for manufactured goods. A summary of Leak's results is presented in Table 1. Imports were split up into two categories: the first category, sample A, relates to classes of commodities of which domestic production exceeded $£ 1$ million in 1934. Two major features stand out: first, import prices were lower than those for similar domestic products. Secondly, there was a fall of approximately 19 percentage points in the relative price of imports from 1930 to 1933; this corresponds closely to the average duty imposed in 1933. This indicates that the domestic price of imports (average value plus duty) relative to the average value of domestically produced goods was not substantially altered by the tariff (see final column of Table 1). This would imply that for sample A, domestic manufacturers took advantage of the tariff to increase prices or that importers decreased their prices by a similar amount, or a combination of both processes.

Sample B was chosen on different criteria, being those goods for which imports in 1930 accounted for at least a third of the domestic market. In 1930 the relation of average values of imports to average values of domestic products was consistently lower for sample $B$ than for sample $A^{1}$. The impact of the tariff was to make

${ }^{1}$ Leak suggests that this may be because a price advantage was required to enter the UK market. However, this may also reflect the pricing strategies of foreign firms in order to take a rising share of the UK market. 
Table 1: Imports Liable to Duty (Millions of Pounds)

Sample A

As Declared

1930

1933

1934

1930

1933

1934

Source: Leak (1937, p. 583) (a)

As Declared
plus duty

(b)

87.2

37.1 $\begin{array}{ll}34.4 & 40.7\end{array}$
At Average

values of goods produced Domestically

(c)

91.8

41.0

44.2 $\mathrm{a} / \mathrm{c}$

(\%)

$\mathrm{b} / \mathrm{c}$

95.0

76.6

95.0

90.5

$77.7 \quad 92.1$

Sample B

$\begin{array}{ll}\text { As Declared } & \begin{array}{l}\text { As Declared } \\ \text { plus duty }\end{array}\end{array}$

(a)

39.6

19.0

21.4 (b)

39.6

22.5

25.3
At Average

values of goods produced Domestically

(c)

the internal price of sample B imports (inclusive of the tariff) some 10 per cent below the price of similar home produced goods compared with 20 per cent below in 1930 . Thus in 1933/34, these imports were approximately 10 per cent less competitive in the domestic market compared with 1930. Leak suggested that this relationship prevailed because domestic manufacturers were able to reduce prices due to expanding production.

Leak's evidence on pricing behaviour shows that the inflationary effects of tariffs were not always strong in the depressed conditions of the early 1930s. This result has some intuitive appeal. In a depression period, with a high level of excess capacity, the inflationary effect of tariffs will be expected to be small (ForemanPeck, 1979; 1981). Moreover, under conditions of oligopolistic competition tariffs will lead to falling mark-ups for imported goods, increasing the degree of competition for domestic producers; the existence of economies of scale may encourage domestic producers to keep their new competitive edge against imported goods by not raising prices. Finally, the protectionist response of the early 1930s is general to the world economy; what will matter in determining changes in international competitiveness is the relative impact of tariffs on prices. The average tariff changes of France, Germany and America were comparable to those of the UK during 1927-31. Thus, although there is clear evidence that the real effective ex- 
change rate appreciated between 1932-37 (Broadberry, 1986; Redmond, 1980) this cannot simply be attributed to the effects of the tariff. Moreover, as noted above, the policies of devaluation and tariffs complemented each other in the impact period by giving domestic producers a higher share of the domestic market in 1932-34.

The most direct effect of tariffs is expected to be on imports. Despite a significant growth of national income between 1929-37 imports of manufactures fell by 17.6 per cent, a sharp contrast to the rise of 65.7 per cent between 1920-29. The result was a very large fall in the share of imports of manufactures relative to net manufacturing output (Maizels, 1963; Kitson and Solomou, 1990). The downward shift of imports was also observed for aggregate imports as a proportion of GDP (Matthews et al., 1982; Beenstock and Warburton, 1983). In the face of major changes in world commodity prices in the early 1930s and the devaluation of sterling in 1931 we clearly cannot attribute the fall in imports only to the effects of the General Tariff. However, there exists a prima facie case that the new policy contributed to these trends. Since the General Tariff had its greatest impact on manufacturing imports we need to consider whether tariffs had a significant effect on this component of demand. Kitson and Solomou (1990) test this by estimating an import function for UK manufacturing imports during the period 1924-38.

Specifying the import function for manufactures as:

$\log M=a+b_{1} \log Y+b_{2} \log P+b_{3} \tau+\varepsilon$

$M=$ Manufacturing imports at constant prices

$Y=$ Real GDP

$P=$ Relative price of foreign to bome manufactures

$\tau=$ ad-valorem tariff rate

Specifying the import function in this general form explicitly considers the impact of the tariff, controlling for the effect of other important variables. The results are presented in Table 2. The fit gives an $R^{2}$ value of 0.89 . All the variables have the expected sign and the income and tariff coefficients are statistically significant at the 99 per cent confidence level. The relative price variable is significant at the 95 per cent level (one-tailed test). The results suggest that UK manufacturing imports were income elastic with an elasticity above 2 . The tariff had a large depressing effect on import demand - a one percentage point increase in tariff rates resulted in a 3.4 percentage change in manufacturing imports. The relative price effect is significantly smaller (a one per cent change in relative prices gave rise to a 1.06 per cent change in manufactured imports) ${ }^{2}$.

2 Imposing the restriction that the coefficient on $\log \mathrm{P}$ and $\mathrm{t}$ are equal is rejected (Kitson, Solomou, 1990). 
Table 2: Regression Results for UK Manufacturing Import Function 1924-38 ( $t$ values in parenthesis)

Results of Regressing:

$$
\log M=\alpha+\beta_{1} \log Y+\beta_{2} \log P+\beta_{3} \tau+\varepsilon
$$

$\begin{array}{lrr}\alpha & -6.772 & -(1.83) \\ \beta_{1} & 2.114 & -(7.41) \\ \beta_{2} & -1.064 & -(1.86) \\ \beta_{3} & -0.034 & -(10.30)\end{array}$

$\mathrm{R}^{2}=0.89 \mathrm{DW}=2.07 \mathrm{~F}=37.02$

Note: $P$ relates to the lag of the relative price variable; the tariff rate used aims to capture the effect of the policy change in 1932 and takes the value of zero between 1924-31 and the manufacturing average tariff rate reported in Kitson and Solomou (1990), Table A4.1 between 1932-38.

These results suggest that the impact of tariffs on import demand did not work through a simple price effect; the tariff effect was significantly higher than the non-tariff relative price effect. One interpretation may be that the tariff (because of its permanence) is capturing a long-run price elasticity of demand for imports which is significantly higher than the short run elasticity. The results are also consistent with the view that tariffs had significant indirect effects on the demand for imports; to the extent that tariffs stimulated scale-intensive industries, the behaviour of pricing and production of such industries had a significant indirect effect on import demand.

Given the degree of excess capacity in 1932, and the success of tariffs in reducing the demand for imports, protection is expected to generate a process of import substitution in production. The 'newly-protected' industries of 1932 received a favourable stimulus, improving their standing relative to the non-protected and already protected industries (for example, under the 1921 Safeguarding of Industries Act). In an empirical evaluation of this hypothesis Richardson (1967, p. 249) concludes:

\section{'The tariff had little effect on the growth of newly protected industries between 1930 and 1935'.}

This conclusion was based on Richardson's evaluation of the effects of protection on output, employment and trade in the newly protected industries of 1932 relative to those protected earlier. Richardson's argument is developed in two steps. The first simply compares the newly protected industries with other industries during the benchmark years 1930 and 1935 (the choice of these two years is determined by the available data: the censuses of production provide extensive disaggregated data). Given that between 1930 and 1935 the fall in imports in newly protected industries was less than the fall in imports of other industries, Richardson favours a non-tariff explanation for the healthy performance of the newly protected industries: recovery in the newly protected sector was thus seen as 
simply reflecting general economic recovery in the 1930s. The second step of Richardson's evidence is based on calculating import replacement ratios for the newly protected and other industries between 1930 and 1935. The Import Replacement Ratio of an industry is defined as:

$$
\text { IRR }=\frac{\text { Rise in Gross Output }- \text { Change in Exports }}{\text { Fall in Imports }}
$$

If a process of import substitution is observed in the 1930s then the fall in imports should lead to a proportional expansion of production for the home market (rise in gross output minus change in exports), assuming a constant level of demand. Thus, ceteris paribus, the ratio should tend to unity if import substitution is successful (a one per cent fall in imports should result in a one per cent increase in production for the home market). Given that the level of demand was not constant Richardson tests for the impact of the tariff by comparing the relative performance of the newly protected and other industries between 1930-35; if the tariff succeeded in generating a process of import substitution then the IRR is expected to be closer to unity for the newly protected industries than for other industries. In fact the IRR takes the value of 3.0 for the newly protected industries and 2.0 for other industries. From this evidence, Richardson concludes that import substitution was not observed in the 1930s recovery and thus industry output movements were independent of tariffs.

Kitson and Solomou (1990) question the methodology behind this result. A major weakness in Richardson's analysis is the implicit assumption that the newly protected and other industries begin from similar initial conditions in 1930. There is no attempt to compare the economic performance of the newly protected and other industries over a longer period that would allow us to test this assumption. The initial conditions in the 1920 s will be unimportant only if industries were comparable in economic performance. We know this was not the case. The newly protected industries of 1932 consisted of many of the under-performing industries of the 1920s. The relevant question that Richardson's study does not address is the extent to which protection in 1932 reversed this path of relative decline. In order to evaluate this we need more information on the behaviour of the two groups of industries in the pre-protection period. Only by making such inter-period comparisons can we hope to test for the effects of policy changes.

The data contained in the Censuses of Production of 1924, 1930 and 1935 are at a sufficient level of disaggregation to allow us to distinguish the performance of the newly protected industries of 1932 relative to other industries. However, instead of comparing the relative position of the newly protected industries only for the years 1930 and 1935, we can use the benchmark comparisons of 1924,1930 and 1935 as a way of capturing changes in relative performance in the light of the initial conditions faced by different industries before the policy shift in 1932. Thus, the inter-period difference in performance between 1924-30 and 1930-35 is the relevant measure to consider. The import duties of 1932 covered the majority of manufacturing industry, accounting for some 85 per cent of manufacturing out- 
put. The remaining industries had been protected under earlier legislation, including motor cars, scientific instruments and synthetic chemicals.

In order to evaluate whether sectoral growth was stimulated by tariffs let us consider the relative performance of the newly protected industries with respect to output and productivity growth. Output growth in the newly protected group of 1932 was stagnant between 1924-30, whilst other industries saw a growth of 2.7 per cent per annum (see Table 3). However, during 1930-35 there occurred a substantial turnaround as the newly protected group grew at 3.8 per cent per annum whilst the other industries grew at 2.3 per cent per annum. The impact of the policy shift on rates of productivity growth was also favourable (see Table 4).

Table 3: Output Indices for the Newly Protected and Non-Newly Protected Manufacturing Sectors $(1935=100)$

Newly Protected Non-Newly Protected

1924

83.22

82.83

76.13

1930

100.00

89.18

100.00

Growth Per Annum (\%)

$\begin{array}{lll}1924-30 & -0.1 & +2.7 \\ 1930-35 & +3.8 & +2.3\end{array}$

Source: Kitson and Solomou (1990, p.77).

Table 4: Labour Productivity Indices for the Newly Protected and Non-Newly Protected Sectors

Newly Protected Non-Newly Protected

1924

1930

85.1

85.4

$87.4 \quad 93.0$

1935

100.0

100.0

Growth Per Annum (\%)

$\begin{array}{lll}1924-30 & +0.45 & +1.43 \\ 1930-35 & +2.73 & +1.46\end{array}$

Source: Kitson and Solomou (1990, p.77).

The General Tariff of 1932 is correlated with a turnaround in the performance of UK manufacturing industries. Studies that have not managed to distinguish this effect have confused a number of very different economic processes. Comparing the newly protected industries of 1932 with the performance of other industries only in the 1930s (as Richardson has done) is equivalent to describing the life cycle and business cycle behaviour of these industries. By taking a longer run comparison over 1924, 1930 and 1935 we can document the magnitude of change in the 
1930s relative to the 1920 s which is more likely to capture the impact of the protectionist policy regime.

As has been argued above, the structure of protection, as measured by effective protection rates, offers further insights into the expected effects of tariffs. The concept of effective protection was first used by Capie (1978) to analyse the effects of the tariff structure on the British recovery of the 1930s. However, one should not regard effective protection rates as being assumption free. The calculated effective rates of protection depend very much on the way in which protected industries are assumed to behave. The assumption often made in studies of effective protection is that the law of one price holds in the domestic market, and that the country concerned is a small participant in the world market, so that any tariff has no effect on the world price of the goods concerned. The implication of this is that a tariff raises the prices of both imports and home sales to the domestic market by the full amount of the tariff. This assumption is unlikely to hold in a major depression (Foreman-Peck, 1979).

Another feature of the approach is that non-tradable industries (such as building) will almost certainly face some increase in costs ${ }^{3}$, but they are assumed not to raise their prices. As a result such industries will have a negative rate of effective protection. In this respect the approach suggests that protection hindered economic recovery during the 1930 s, because the housing sector played an important role in recovery. However, we need to be aware that effective protection represents only one framework for analysing the resource flow effect of tariffs on the industrial structure. Nominal tariff rates will also be important to the extent that they influence consumption decisions and the macroeconomic process of import substitution. Moreover, effective protection rates are calculated using macroeconomic assumptions that are clearly restrictive, such as full employment. Thus, paradoxically, if the income effect of the tariff is large enough, non-tradable industries may not be adversely affected.

Another feature that has not been fully emphasised in the literature is that effective protection rates can be calculated across a number of domains. The literature on Britain has focused on intra-industry rates (Capie, 1978; Kitson, Solomou and Weale, 1991). However another feature of British tariffs is that food and raw materials could still be imported tariff free. Thus, the manufacturing sector was relatively favoured by the tariff structure relative to the primary sector. If we take an inter-sectoral perspective to economic recovery in the 1930s, the evidence suggests that explaining the rapid revival of the manufacturing sector is central to the story. In terms of sectoral growth accounting, it is clear that to understand the strength of UK economic revival in the 1930s, the building sector is of second order importance to the role of the manufacturing sector (Kitson and Solomou, 1991).

${ }^{3}$ During the 1930s imports accounted for approximately 40 per cent of inputs into the industry. 
The overall policy regime also needs careful consideration when thinking about the effects of tariffs. The use of protection as an instrument of national economic revival in a flexible exchange rate regime has been a controversial policy issue. The historical literature has drawn on Mundell's (1961) seminal paper to argue that tariffs were unlikely to have been expansive in the circumstances of the 1930s (Broadberry, 1986). Mundell recognised that under fixed exchange rates, and in the absence of extensive retaliation, a tariff may generate higher output and employment via import substitution effects. However, under flexible exchange rates, the appreciation of the real exchange rate, resulting directly from the imposition of tariffs, will render commercial policy ineffective. Applying such a framework to the 1930s experience is not straightforward. First, in the circumstances of the 1930 s the sterling exchange rate was clearly operating in a framework of managed exchange rates, not floating rates. Hence, although the real effective exchange rate appreciated during 1932-37 (Redmond, 1980) this cannot simply be attributed to the General tariff. Secondly, the British trade data shows that trade policy generated persistent changes during the early 1930 s. The import ratio for manufactured goods saw a sharp fall in 1932 (by about one third), a fall that was sustained from 1932 through 1938. Such behaviour cannot be explained within Mundell's floating exchange rate model, which implies a long-run equilibrium that is not affected by trade policy. Clearly, the evidence is consistent with a concept of path-dependence. The trade policy changes of 1931-2 generated large competitiveness changes that were complementary on impact. Moreover, the induced changes were large enough to generate a permanent change in the import penetration of the economy. Even if the Mundell model is seen as offering an explanation of the behaviour of the real exchange rate in the 1930s it does not follow that tariffs were neutral. Clearly, trade policy had large and persistent effects during 1932-4.

The evidence presented suggests that the impact of tariffs was important to the recovery of the UK economy after 1932. Between 1932-37 the U.K. economy witnessed a marked fall in import ratios that can be partly attributed to the impact of the General Tariff. The newly protected sector of 1932 saw an improvement in economic performance relative to the poor performance of the 1920s; these industries significantly increased their annual growth rate in the period 1930-35 compared with 1924-30. In contrast the group of industries protected throughout the inter-war saw a fairly constant growth performance between the two periods. These conclusions need to be kept in perspective. Tariffs were successful in stimulating economic revival, partly because they were acting as a catalyst in the context of very favourable conditions. For example, devaluation contributed to the recovery by improving competitiveness and facilitating the introduction of cheap money in 1932. Similarly the process of wage bargaining did not prevent the new trade policies from generating improved competitiveness and initiating import substitution.

The framework that has been set out above suggests that the national effects of trade policy need to be evaluated country by country. Briefly comparing Britain and France illustrates the dangers of generalising. In France the average tariff rate 
rose from $23 \%$ in 1927 to $38 \%$ by 1931 (Liepman, 1938). As noted above France also used quotas as a form of new protection during the 1930s. Clearly French trade policy represented a quantitative incremental policy change, to be distinguished from the General Tariff in Britain, which represented the end of unilateral free trade. Moreover, the main aspect of tariff changes in France was the rise in the tariff on foodstuffs, which rose from $19 \%$ in 1927 to $53 \%$ in 1931 . The tariff on manufactures rose only marginally from $26 \%$ to $29 \%$ over the same period (Woytinksy and Woytinksy, 1955). Hence, the major aspect of French policy was to protect the agricultural sector from the collapse of international food prices. In terms of the structure of protection, the tariff changes of the 1930s meant that effective protection rates were clearly rising in agriculture relative to manufacturing. The effect on industrial sector cyclical revival was likely to be limited and indirect. In addition the overall policy regime that France sustained as a member of the Gold Bloc was unfavourable to recovery during the 1930s. The fate of the Gold Bloc during the 1930s was one of low cyclical growth rates, relative to the countries that exited from the gold standard (Eichengreen and Sachs, 1985; Solomou, 1996). To the extent that tariffs impacted to reduce imports and import ratios in the 1930s their effect on national economic recovery was positive, to the extent that tariffs helped to sustain the gold parity of France, their effect was adverse.

\section{Bilateralism and Regionalism}

Developments in the international trading system during the inter-war period are considered as the prime example of a collapsing multilateral trading system (Arndt, 1944; Lewis, 1949; Nurkse, 1944). For many contemporary observers the increase in discriminatory protectionist policies, partly resulting from the world depression of 1929-33, was assumed to have led to a collapse of multilateral trading patterns (League of Nations, 1936, 1942; PEP, 1937; Pomfret, 1988). This view has now become accepted in surveys of the period (Kindleberger, 1973; 1989; Capie, 1994).

A quantitative evaluation of this proposition is undertaken by considering an index of bilateralism for the four core industrial countries (Britain, France, German and America) during the period c.1870-1938. Bilateral trade entails the direct balancing of trade between pairs of countries. This contrasts with multilateral or triangular trade where a country will purchase goods (imports) from one trading partner but will sell (exports) to another country. There was a significant increase in the number of bilateral agreements during the 1930s. A number of these agreements sought to achieve bilateral trade balances while others provided preferential trading arrangements which represented a departure from the multilateral Most Favoured Nation policy (Irwin, 1993).

A simple measure for bilateralism is Pomfret's adaptation of the Grubel-Lloyd intra-industry trade index (Pomfret, 1988, p. 51): 
$X_{i}=$ value of exports from country $i$

$M_{i}=$ value of imports to country $i$

$$
\mathrm{B}=\left[1-\left\{\frac{\sum_{i=1}^{n}\left|X_{i}-M_{i}\right|}{\sum_{i=1}^{n}\left(X_{i}+M_{i}\right)}\right\}\right] \times 100
$$

This index is constructed in such a way that if all trade is settled on a bilateral basis, i.e.

$$
\sum_{i=1}^{n}\left|X_{i}-M_{i}\right|=0
$$

then B will take the value of 100 but if all trade is settled on a multilateral basis, then

$$
\sum_{i=1}^{n}\left|X_{i}-M_{i}\right|=\sum_{i=1}^{n}\left(X_{i}+M_{i}\right)
$$

and the index will take the value of zero. Thus, if the bilateral agreements of the 1930 s led to increase bilateralism this would lead, ceteris paribus, to an increase in the value of $B$. The value of this index is affected by business cycle shocks that affect trading relations differently across countries. Thus, a major shock that affects countries to different degrees, in terms of amplitude, timing and duration, will displace existing trading patterns giving rise to cyclical fluctuations in this measure of bilateralism. Despite this the long run movements offer us quantitative information on the effects of more persistent policy changes such as regionalism and discriminatory protectionist measures.

Figures 1-4 plot the long run data for the UK, France, Germany and America over the late $19^{\text {th }}$ Century and the inter-war period. Although all countries display long run shifts it is not clear that the 1930s have an observable effect on the structure of trade settlements. With the exception of Germany no other country sees a discernible increase in bilateralism in the 1930 s relative to the 1920 s and pre-1913 trends. In the case of France and Britain the level of inter-war bilateralism is comparable to that observed in the immediate pre-1913 period. In the case of America the average level of the index is higher than that observed over the period 1875-1913; however this is valid for the inter-war period as a whole, not the 1930s. A number of studies have suggested that the period 1870-1914 witnessed a trend towards multilateralism (Saul, 1960). The trends for France, Germany are consistent with this hypothesis but the trends for the USA and the UK do not show a stable trend towards multilateralism in the pre-1913 period. 
Figure 1: Bilateralism Index, $U K$

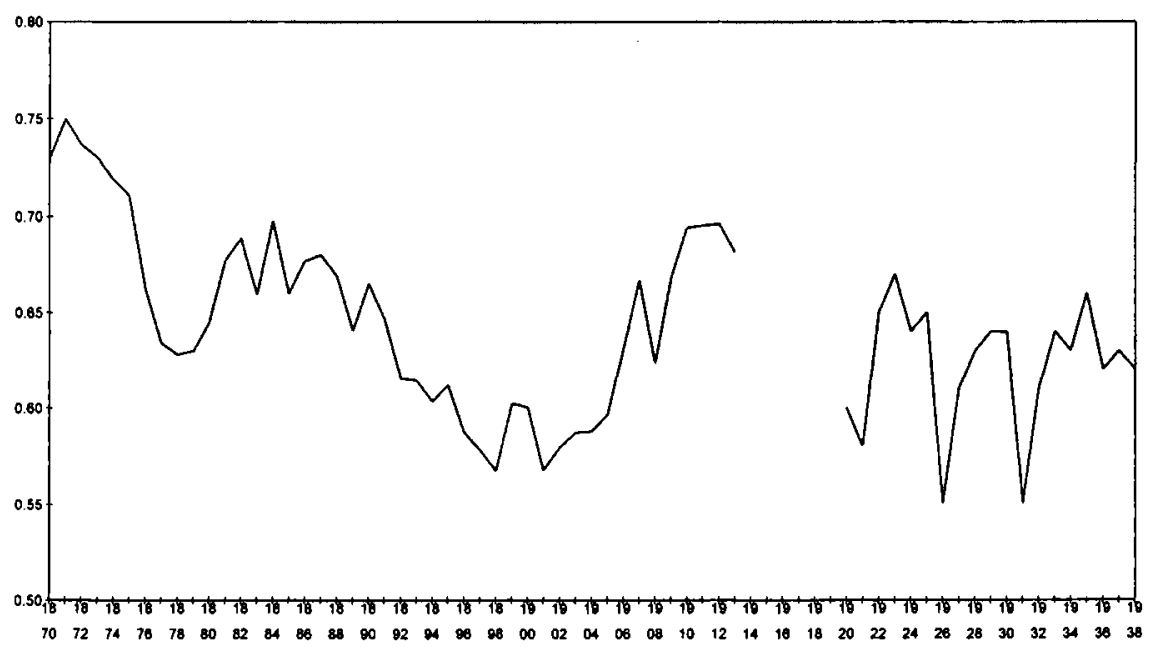

Figure 2: Bilateralism Index, France

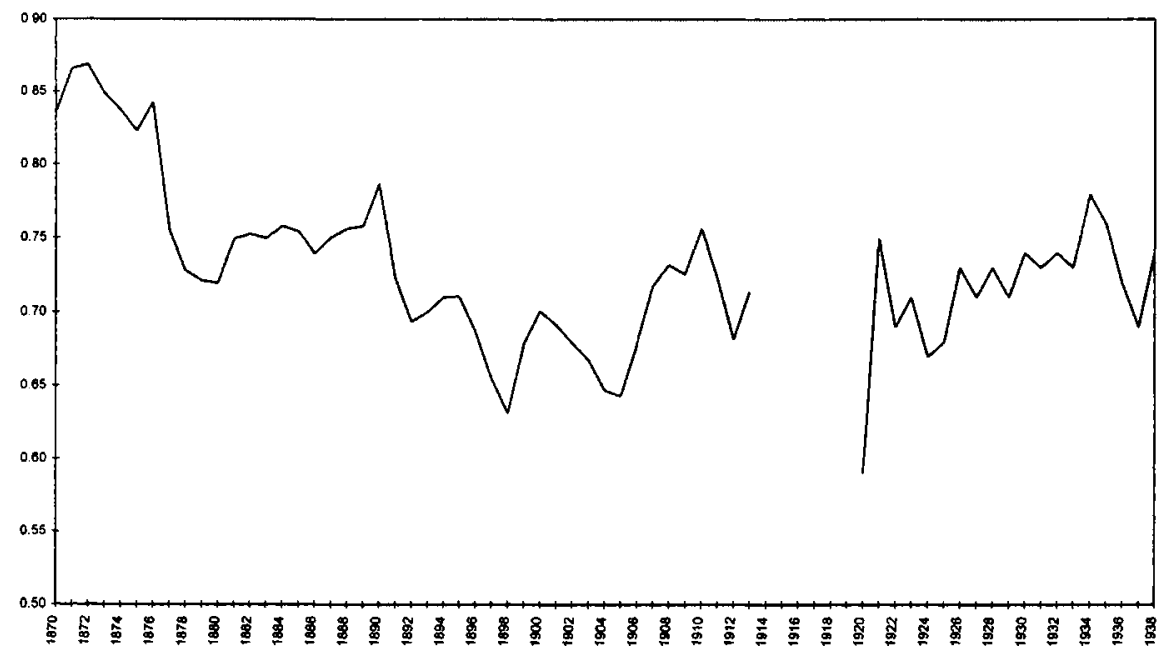

Why did the proliferation of bilateral trading agreements during the 1930 s not lead to a rise in the overall level of bilateralism? It seems clear that, with the exception of Germany, the impact of discriminatory trade agreements in the 1930s was not to increase bilateralism but to foster regionalism. For countries such as the UK, France, Netherlands and Italy a growing proportion of trade was conducted with their respective Empires (Tovias, 1988). Furthermore, currency blocs also 
Figure 3: Bilateralism Index, Germany

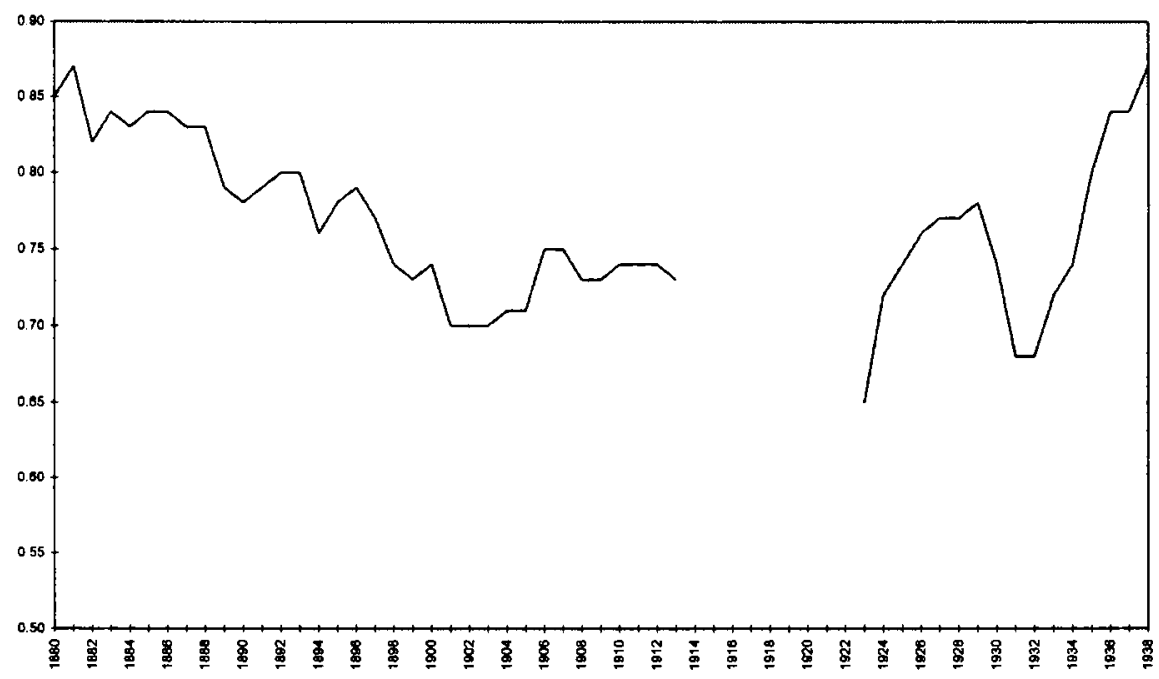

Figure 4: Bilateralism Index, USA

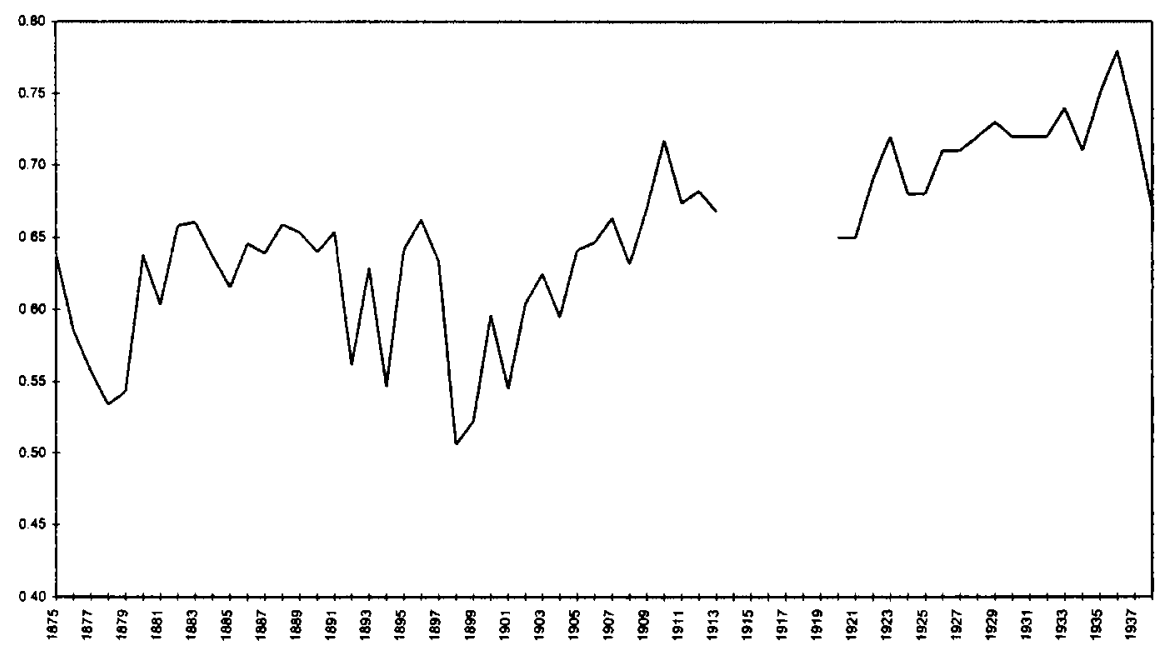

grew in importance as countries sought exchange rate stability within different policy zones. As the scale of trade expanded within these regional blocs a form of 'regional multilateralism' evolved in importance during the 1930s. The German experience is a unique outcome of the military objective of autarky and should not be seen as representative of the impact of trade policies in the 1930s (Kitson, 1992; Kitson and Solomou, 1995). 
The evidence suggests that the discriminatory trade policies of the $1930 \mathrm{~s} \mathrm{did} \mathrm{not}$ result in the widespread increase in bilateralism. The contrasting experience of Germany and the rest of the world illustrate this point clearly. The long-run evidence presented here does not support Pomfret $(1988$, p. 50) who notes that in the 1930 s "increased discrimination was reflected in a growing resort to bilateralism". The experience of Germany cannot be separated from the Nazi policy of striving for autarky for political and military reasons. Other countries, however, sought pragmatic solutions to the shocks of the 1930s around regional blocs. Bilateralism was not an inevitable outcome, despite the signing of bilateral trading agreements. The evidence suggests that discriminatory trade policies during the 1930 s resulted in new trade blocs, but within the trading bloc trade continued to be conducted on a 'multilateral' basis. A clear distinction between the development of trading blocs and the collapse of multilateralism is essential to understand the experience of the inter-war years.

\section{Conclusion}

The study of trade policy remains a politicised topic. The economic history of inter-war trade policy has been constrained by a post-war vision on the problem. The evidence considered above suggests that we have a long way to go before we can claim to understand the effects of trade policy on the world depression and recovery during the 1930s. Only by carefully building evidence at the national level can we hope to move towards an aggregate picture. Those who claim to know the answer need to articulate their case. Finally, to understand why nations pursued trade policies we need to bear in mind the overall problems facing economies during the inter-war period. In a world with few policy instruments and severe economic shocks, national protection provided a viable and in some cases an effective policy tool.

\section{References}

Abramovitz, M., The Passing of the Kuznets Cycle, in: Economica 35 (1968) 349-367

Arndt, H. W., The Economic Lessons of the 1930s (Oxford 1944)

Beenstock, $M$. / Warburton, $P$., Long Term Trends in Economic Openness in the United Kingdom and the United States, in: Oxford Economic Papers 35 (1983) 130-140

Bairoch, P., Commercial Policies and Economic Development in History: Myth and Reality of Protectionism, in: Journal of Regional Policy 4 (1986) 512-534

Bhagwati, J., Multilateralism at Risk: The GATT is Dead, Long Live GATT, in: The World Economy 13 (1990) 149-169

Bhagwati, J. / Irwin, D., The Return of the Reciprocitarians: US Trade Policy Today, in: The World Economy 10 (1987) 109-130

Broadberry, $S$. N., The British Economy Between the Wars: A Macroeconomic Survey (Oxford 1986) 
Capie, F, The British Tariff and Industrial Protection in the 1930s, in: Economic History Review 31 (1978) 399-409

Capie, F., Depression and Protectionism: Britain between the Wars (London 1983)

Capie, F., Effective Protection and Economic Recovery in Britain, 1932-1937, in: Economic History Review (1991)

Capie, F., Trade Wars; A Repetition of the Inter-War Years, Current Controversies No. 2, (Institute of Economic Affairs, London 1992)

Capie, F., Tariffs and Growth (Manchester 1994)

Customs and Excise Department, Annual Statement of Trade of the United Kingdom 1921, 1925, 1929, 1933, 1935 and 1939, HMSO, London

Eichengreen, B. J., The Political Economy of the Smoot Hawley Tariff, in: Research in Economic History 11 (1989) 1-44

Eichengreen, B. / Irwin, D., Trade Blocs, Currency Blocs and the Disintegration of World Trade in the 1930s (1993) mimeo

Eichengreen, B. / Sachs, J., Exchange Rates and Economic Policy in the 1930s, in: Journal of Economic History 45 (1985) 925-946

Foreman-Peck, J. S., Tariff Protection and Economies of Scale: The British Motor Car Industry before 1939, in: Oxford Economic Papers 31 (1979) 237-257

Foreman-Peck, J. S., The British Tariff and Industrial Protection in the 1930s: An Alternative Model, in: Economic History Review 34 (1981) 132-139

Foreman-Peck, J. S. / Hughes-Hallet, A. / Ma, Y., The Transmission of the Great Depression in the United States, Britain, France and Germany, in: European Economic Review 36 (1992) 685-694

Irwin, D. A., Multilateral and Bilateral Trade Policies in the World trading System: An Historical Perspective, in: J. De Melo, a Panagariya (eds.), New Dimensions in Regional Integration (Cambridge 1993)

Kindleberger, C. P., The World in Depression 1929-39 (Berkeley 1973)

Kindleberger, C. P., Commercial Policy Between the Wars, in: P. Mathias, S. Pollard (eds.), The Cambridge Economic History of Europe, Vol. VIII (Cambridge 1989)

Kitson, M. / Michie, J., Depression and Recovery: Lessons from the Inter-war Period, in: J. Michie, J. Grieve Smith (eds.), Unemployment in Europe (London 1994)

Kitson, M. / Solomou, S., Protectionism and Economic Revival: The British Inter-war Economy (Cambridge 1990)

Kitson, M. / Solomou, S. / Weale, M., Effective Protection and Economic Recovery in the UK in the 1930s, in: Economic History Review 44,2 (1991) 328-338

Kitson, M. / Solomou, S., Bilateralism in the Interwar World Economy, in: Bulletin of Economic Research 47, 3 (1995) 197-219

Krugman, P., Is Bilateralism Bad?, in: E. Helpman, A. Razin (eds.), International Trade and Trade Policy (London 1991)

League of Nations, Balance of Payments and Foreign Trade Balances, Vol. II, League of Nations, Geneva

League of Nations, International Trade and Balance of Payments, 1913-1927, Vol. II, 19261928, Vol. III, League of Nations, Geneva

League of Nations, International Trade Statistics, 1930, 1931, and 1932, 1934, 1935, 1937 and 1938, League of Nations, Geneva

League of Nations (1936): World Economic Survey 1935/36, League of Nations, Geneva

League of Nations (1939a): Review of World Trade 1938, League of Nations, Geneva

League of Nations (1939b): World Economic Survey 1938/9, League of Nations, Geneva

League of Nations (1942): Network of World Trade, League of Nations, Geneva

Leak, H., Some Results of the Import Duties Act, in: Journal of the Royal Statistical Society, C. Part IV (1937) 558-595

Lewis, W. A., Economic Survey 1919-1939 (London 1949)

Liepmann, H., Tariff Levels and the Economic Unity of Europe (London 1938) 
Maizels, A., Industrial Growth and World Trade (Cambridge 1963)

Matthews, R. C. O. / Feinstein, C. H. / Odling-Smee, J. C., British Economic Growth, 18561973 (Oxford 1982)

Nurkse, R., International Currency Experience, League of Nations (Geneva 1944)

PEP (Political and Economic Planning) (1937): Report on International Trade, PEP, London

Pomfret, $R$., Unequal Trade: The Economics of Discriminatory International Trade Policies (Oxford 1988)

Redmond, $J$., An Indicator of the Effective Exchange Rate of the Pound in the NineteenThirties, in: Economic History Review 33 (1980) 83-91

Rooth, T. J. T:, Tariffs and Trade Bargaining: Anglo-Scandinavian Economic Relations in the 1930s, in: Scandinavian Economic History Review 34 (1986) 54-71

Saul, S. B., Studies in British Overseas Trade 1870-1914 (Liverpool 1960)

Solomou, S. N., Themes In Macroeconomic History: The UK Economy 1919-1939 (Cambridge 1996)

Solomou, S. N., Economic Cycles (Manchester 1998)

Statistisches Reichsamt (1933 and 1938): Monatliche Nachweise über den Auswärtigen Handel Deutschlands, Ergänzungsheft, Berlin

Svennilson, I., Growth and Stagnation in the European Economy (Economic Commission for Europe, Geneva 1954)

Temin, P., Lessons From the Great Depression (Cambridge, Mass. 1989)

Tovias, A., Trade Discrimination in the Thirties and Eighties, in: World Economy 11 (1988) 501-514

United States Tariff Commission (1942): Foreign Trade and Exchange Controls in Germany, Report 150, Washington

Woytinksy, W. S. / Woytinksy, E. S., World Commerce and Governments-Trends and Outlook ( 1955) 
